\title{
Semi-Clandestine Judaism in Early Modern France: European Horizons and Local Varieties of a Domestic Devotion
}

\author{
Carsten L. Wilke
}

If historians of the Portuguese Jewish diaspora share a mental map of their subject, this is due in part to a famous text from 1631 that the Amsterdam rabbi Saul Levi Mortera wrote in reply to the questions of a Spanish priest from Rouen. In this unpublished manuscript, Mortera outlines a three-tiered Jewish geography of Europe: he praises those conversos who had left Spain and Portugal and joined Jewish communities; he pities and excuses those who were trapped on the Iberian Peninsula by the Inquisition's control of emigration; and he severely blames those who had managed to cross the Pyrenean border but were reluctant to officially become Jews, preferring to settle in safe countries where they could officially be Christians and secretly Jews.

This last named category on the moralized map of Sephardic residence options was obviously that of the Portuguese merchant colonies in France, the Southern Netherlands, and several Italian cities, where New Christian immigrants had to conform to public Catholic worship, but were not threatened by inquiries into their private practice. What is remarkable about Mortera's text is that this region is not described as an intermediary zone between the realms of the Kahal and of the Inquisition, but as an extreme situation suigeneris in religious terms.

Those who live in countries where emigration is allowed and from where they can leave freely and without any obstacle to any destination of their choice are in total abjection with the Lord and destined to damnation, because they are truly the worshippers of money. Caught in a vile desire to accumulate wealth, they cheat God (or believe to cheat Him) for the love of the world, and they cheat the world for the love of God, because they believe that they have fulfilled their duty by holding Him dear in their hearts. ${ }^{1}$

1 Amsterdam, Ets Haim cod. 48A21: "Aquellos que habitan en reinos donde no se les impide la salida y libremente sin ningún impedimiento pueden ir donde mejor les parezca, estos tales

(C) CARSTEN L. WILKE, 2019 | DOI:10.1163/9789004392489_006

This is an open access chapter distributed under the terms of the prevailing CC-BY-NC License at the time of publication. 
Mortera's tripartite picture is inevitably shared by the historian in one respect, namely that of archival documentation. All research on crypto-Judaism in the Iberian countries has its underpinning in the fund of Inquisition files in the national archives of Lisbon, Madrid, and Mexico City, just as any serious historiography on the Portuguese community of Amsterdam explores the Jewish community records in that town's public archives. Historiography on the French crypto-Judaism can occasionally draw information from these two collections, but it is mainly left with the dispersed documents that must be painfully gleaned and put together from the archives of French jurisdictions, notaries, and parish churches, producing sources that offer information only in a very unsatisfactory quantity and quality for a historian of religion.

My subject in this essay, namely the religious and social profile of the approximately two thousand New Christians settling in seventeenth-century France, leads into a historical environment that is characterized by a weak community organization, much institutional improvisation, and rather dynamic forms of symbolic identity. Describing them with the two source categories at our disposal - those produced by the Inquisition of Madrid and the Kahal of Amsterdam - confronts us with the heavy bias of their authors. Both points of view need to be compared with each other, as well as with new archival and literary sources.

Let me start with a few remarks on the state of the art. Not unlike Mortera, other seventeenth-century Jews have fit the migratory history of the Portuguese Jews into a schematic model, which locates French crypto-Jewry on a timeline of progress from apostasy to normative Judaism, or on a hierarchy of space from the clandestine periphery to the center in Amsterdam. A few years after Mortera lambasted crypto-Judaism in France, the merchant-poet João Pinto

son totalmente abominados del Señor y aparejados para perdición, porque son verdaderamente adoradores del oro, siendo así que por un vil interés de acomular hacienda engañan, o piensan engañar a dios por amor del mundo, y al mundo por amor de dios, y piensan estos que teniendo el corazón bueno con el Señor tienen satisfecho a su obligación." They have to practice and not only to believe the law, and it would be better for them not to have any idea of the truth than to deny it: "debían considerar cuán grande ingratitud usan con su creador que los sacó del fuego de Sedom, y ellos como la mujer de Lot, en lugar de seguir el camino que deben y ponerse en salvo, miran atrás y quedan en medio hechos estatuas de sal." An interesting variant reading in manuscript Ets Haim 48C20 redirects Mortera's polemics against those who do not observe the law, though they live "en reinos donde no se les impide la libertad en su religion y libremente sin ningun impedimento pueden observar lo que mejor les pareciere." On this text, see the debate between H.P. Salomon, "Haham Saul Levi Morteira en de Portugese Nieuw-Christenen," Studia Rosenthaliana 10 (1976): 127-41, and Yosef Kaplan, From Christianity to Judaism: The Story of Isaac Orobio de Castro, trans. Raphael Loewe (Oxford: The Littman Library of Jewish Civilization, 1989), 328-29. 
Delgado described his retrospective itinerary from Lisbon via Rouen to the Dutch city of Naarden in an apologetic tone, giving all three stations clearly outlined religious meanings: "I came from that city [of Rouen], though it was in no way the destination of my desires, but only a way station (escala) for other more sublime ones."2 Still in 196o, Pinto Delgado's theological geography appeared convincing to Israël Salvator Révah, who believed that France was for most New Christian migrants a mere "way station" (escale) on the flight from the Inquisition to the northern Jewish communities. ${ }^{3}$ Inversely, Zosa Szajkowski placed the Sephardim of France on a no less schematic downward road toward assimilation. ${ }^{4}$

Overcoming these teleological views, Gérard Nahon insisted since the $1980 \mathrm{~s}$ on the idea that the Iberian Jewish diaspora in seventeenth-century Western Europe was built around "two geographic poles: the 'legal' one in Amsterdam and the 'clandestine' one in France." In a perspective of religious history, the type of crypto-Judaism practiced under these circumstances can thus be characterized as the "French model of Marranism" 6 and researched in its own right on an equal footing with the religious culture of Dutch Sephardic Jewry. ${ }^{7}$

In order to explore the socioeconomic context of this religious model, researchers have taken two complementary directions. French urban historians

2 Israël Salvator Révah, "Autobiographie d'un Marrane: Edition partielle d'un manuscrit de João (Moseh) Pinto Delgado," Revue des études juives 119 (1961): 41-130, esp. 103: "Llegando a aquella ciudad, no meta de mis deseos, escala, si, para otros mayores."

3 Israël Salvator Révah, "Les Marranes," Revue des études juives 118 (1959-1960), 29-77, esp. 66. A more recent author who subscribes to the same interpretation is Michèle Escamilla-Colin, "Rouen et la diaspora ibérique," Cahiers du C.R.I.A.R. 15 (1995): 27-48, esp. 46.

4 Zosa Szajkowski, "Population Problems of Marranos and Sephardim of France," Proceedings of the American Academy for Jewish Research 27 (1958): 83-105; "The Marranos and Sephardim of France," in The Abraham Weiss Jubilee Volume, ed. Samuel Belkin (New York: The Abraham Weiss Jubilee Committee, 1964), 107-127.

5 Gérard Nahon, Métropoles et périphéries séfarades d'Occident:Kairouan, Amsterdam, Bayonne, Bordeaux, Jérusalem (Paris: Cerf, 1993), 97.

6 Gérard Nahon, "Le modèle français du marranisme (XVIe-XVIII ${ }^{\mathrm{e}}$ siècles)," Annuaire de l'École Pratique des Hautes Études, Cinquième section: Sciences religieuses 90 (1982): 264; Nahon, "Le modèle français du marranisme: Perspectives nouvelles," in Inquisição: Ensaios sobre mentalidade, heresias, e arte, ed. Anita Novinsky and Maria Luiza Tucci Carneiro (Rio de Janeiro: Edusp, 1992), 227-65; Nahon, "La 'Nation portugaise' de Saint-Esprit-lès-Bayonne du XVI ${ }^{\mathrm{e}}$ au XVIII ${ }^{\mathrm{e}}$ siècle: Escale ou havre de grâce?" in 1492/1992: L'Exode des juifs d'Espagne vers Bayonne, ed. Maïté Lafourcade (Bayonne: Université de Pau, 1993), 1-30, 165-91.

7 This approach is most notably followed by Renée Levine Melammed, A Question of Identity: Iberian Conversos in Historical Perspective (New York: Oxford University Press, 2004), 81-93. 
such as Anne Zink, ${ }^{8}$ Jacques Blamont, ${ }^{9}$ and Jacques Bottin ${ }^{10}$ have laid the stress on the Portuguese's incomplete and problematic insertion into French urban society. Historians of the Jews have rather tended to see the French New Christians as a node in the far-flung merchant networks of the Nação, the Portuguese-Jewish "Nation." Jonathan Israel most aptly describes this position as a kind of in-between-ness on the trans-imperial map of Hispano-Dutch colonial confrontation, as a frontier zone between Amsterdam and Madrid.11 Economic history thus extends Nahon's bipolar model of the Nação to a triangular scheme connecting the Netherlands with France and the Iberian world.

Since Yosef Kaplan's studies, ${ }^{12}$ there has been an increased readiness to focus on nonlinear migration patterns as a major problem of Sephardic history and to interpret them as "evidence of disaffection and nonconformity." I am quoting David Graizbord, who highlighted "the mercantile matrix of renegade behavior,"13 meaning the frequent economic constraints of Franco-Spanish trade that undercut the Jewish integration of individuals and confessional discipline at large. ${ }^{14}$ "The needier the merchant, the more likely he was to

8 Anne Zink, "Une niche juridique: L'installation des Juifs à Saint-Esprit-lès-Bayonne au XVII siècle," Annales—Histoire, Sciences Sociales 49, no. 3 (1994): 639-70; Zink, "Communautés et corps social: Les juifs à Saint-Esprit-lès-Bayonne du XVII ${ }^{\mathrm{e}}$ au début du $\mathrm{XIX}^{\mathrm{e}}$ siècle," in Les Étrangers dans la ville: Minorités et espace urbain du bas Moyen Age à l'époque moderne, ed. Jacques Bottin and Donatella Calabi (Paris: Éditions de la Maison des Sciences de l'Homme, 1999), 313-28.

9 Jacques Blamont, Le lion et le moucheron: Histoire des marranes de Toulouse (Paris: Odile Jacob, 2000), 331 .

10 Jacques Bottin, "La redistribution des produits américains par les réseaux marchands rouennais (1550-1620)," in Dans le sillage de Colomb: L'Europe du Ponant et la découverte du Nouveau Monde (1450-1650), ed. Jean-Pierre Sanchez (Rennes: Presses universitaires de Rennes, 1995), 27-39.

11 Jonathan I. Israel, Diasporas within a Diaspora:Jews, Crypto-Jews, and the World Maritime Empires (1540-1740) (Leiden: Brill, 2002), 245-68, in the chapter titled "Crypto-Judaism in 17th-Century France: An Economic and Religious Bridge between the Hispanic World and the Sephardic Diaspora."

12 See especially Yosef Kaplan, "Wayward New Christians and Stubborn New Jews: The Shaping of a Jewish Identity," Jewish History 8, nos. 1-2 (1994): $27-41$.

13 David L. Graizbord, Souls in Dispute: Converso Identities in Iberia and the Jewish Diaspora, 1580-1700 (Philadelphia: University of Pennsylvania Press, 2004), 12: "I devote considerable attention to the mercantile matrix of renegade behavior. By consciously placing the economic activities of returnees at the center of my interpretation I attempt to ground an understanding of the mentality of these dissidents in their mundane circumstances and interests."

14 Ibid., 176: "In the context of seventeenth-century Iberia and Sephardi France, border crossing was highly 'transgressive,' not because it defied cultural or spatial demarcations that were actually rigid, but because such behavior violated imaginary models of social and religious conformity $[. .$.$] The fact remained that as economic actors and as products$ 
cross the border into Spain - and to do so often."15 From a point of view of religious anthropology, Natalia Muchnik has tried to detect in this flexible religious practice the mechanisms of clandestine collective self-fashioning. This includes linguistic marks of belonging to the "Nation," as well as the semantics of physical bodies and geographical spaces, which suggest that diaspora religiosity should be seen in a very broad transnational range. ${ }^{16}$ The internal diversification of the "Portuguese Nation" between various religious attitudes resembles, as Yosef Kaplan has recently shown, a pattern known from the dynamic of confessionalization in post-Reformation Christianity. ${ }^{17}$

From my side I have, likewise, tried to underscore the systemic character of the apparent religious nonconformity, focusing on the specific functions that the Franco-Portuguese merchant communities fulfilled in the short-term economic cycles of the seventeenth century ${ }^{18}$ Religious flexibility was a highly productive strategy in these merchants' involvement in the contraband trade of the 1630 s, or in the Spanish tobacco monopoly during the 1650 . Literary sources show that the Portuguese Jews did not demonize Spain: the solemn synagogue formula of the "land of idolatry" did not deter anyone from traveling to the Iberian countries in the guise of good Catholics. ${ }^{19}$ The Portuguese "Nation" was certainly extreme, but not at all exceptional in this respect, as Christian merchant groups also showed some degree of pliability in their denominational identity. ${ }^{20}$ Canadian historian Gayle Brunelle has similarly exemplified the idea that the brokerage position of the Portuguese merchant

of Iberian and Judaic cultures, these so-called 'renegades' were an integral part of peninsular society as well as the Sephardi diaspora."

15 Ibid., 89.

16 Natalia Muchnik, De paroles et de gestes. Constructions marranes en terre d'Inquisition (Paris: Éditions de l'EHESS, 2014), 249. Muchnik, ibid., 195, on "l'impact du contexte spatio-temporel sur la religiosité crypto-judaisante et, partant, sur les processus identitaires"; ibid., 198: "On ne saurait isoler les groupements crypto-judaisants péninsulaires et impériaux de la diaspora, en dépit des critiques qu'ils essuient."

17 Yosef Kaplan, "Between Christianity and Judaism in Early Modern Europe: The Confessionalization Process of the Western Sephardi Diaspora," in Judaism, Christianity, and Islam in the Course of History: Exchange and Conflicts, ed. Lothar Gall and Dietmar Willoweit (Munich: Oldenbourg, 2011), 307-41, on France see esp. 319-20.

18 Carsten Wilke, Jüdisch-christliches Doppelleben im Barock: Zur Biographie des Kaufmanns und Dichters Antonio Enríquez Gómez (Frankfurt: Peter Lang, 1994), 31-74.

19 Wilke, "Contraband for the Catholic King: Jews of the French Pyrenees in the Tobacco Trade and Spanish State Finance," in Purchasing Power: The Economics of Modern Jewish History, ed. Rebecca Kobrin and Adam Teller (Philadelphia: University of Pennsylvania Press, 2015), 46-70, esp. 54-55.

20 Gayle Brunelle, The New World Merchants of Rouen, 1559-1630 (Kirksville, MO: Sixteenth Century Journal Publishers, 1991), 156-59. 
community strongly favored an "ambiguous public identity."21 The confrontation between Jewish and Christian believers in the New Christian merchant colonies of Rouen and Bordeaux may in some cases express a deep religious hostility. ${ }^{22}$ However, members of both groups worked together in the same enterprises, and the Catholic denunciations against the crypto-Jews arose as a largely tactical manoeuver at the moment when the Spanish Inquisition started to act against the New Christian fugitives irrespective of their individual persuasions. ${ }^{23}$ Economic cooperation thus led to an attitude that was strongly in conflict with prevailing ideals of confessional borderlines.

Just as Rabbi Mortera hated hypocrites more than renegades, French Catholics' fear of these boundary-crossers was far bigger than their dislike of plain Judaism. As early as 1568, an unpublished French polemical poem against a Portuguese of Nantes first denies him the qualities of the Old Testament saints, then describes him as one of the bleak and bearded Jewish figures that Church frescoes of the Passion use to display in grey colors, and finally affirms that he is even worse than those biblical anti-heroes, namely a Marrano (Maran) who by financial tricks preys on the king's finances. ${ }^{24}$ From the point of view of Christian morals, it was better to deal with a real Jew who wears a yellow hat than with a disguised one. In a polemical book published in 1622, Pierre de Lancre, lawyer at the Parliament of Bordeaux, profusely expressed his dismay at the dangerous infiltration of Judaizers into France. ${ }^{25}$ The Parliament

21 Brunelle, "Jewish Jews and Catholic Jews: Confessionalization and Portuguese New Christians in Early Modern Rouen," in Trouver sa place: Individus et communautés dans l'Europe moderne, ed. Antoine Roullet, Olivier Spina and Nathalie Szczech (Madrid: Casa de Velázquez, 2011), 101-16, esp. 110. See also Brunelle, "Migration and Religious Identity: The Portuguese of Seventeenth-Century Rouen, "The Journal of Early Modern History 7 , nos. 3-4 (November, 2003): 283-311.

22 Brunelle, "Jewish Jews and Catholic Jews," 104: "There clearly was no love lost between the third or so of the Portuguese who adopted an ardent Catholic assimilationist stance and the other two-thirds who were either active Judaizers or ambivalent in their religious leanings and it likely was very difficult for the two groups to live together as one community in Rouen."

23 Muchnik, "De la défense des 'impurs' à la critique du Saint-Office: Le plaidoyer de Juan Bautista de Villadiego (1636)," Revue d'histoire ecclésiastique 101 (2006): 1014-38.

24 "Satyre contre un Juif, 1568," Bulletin du bibliophile et du bibliothécaire 33 (1867): 175-80, esp. 175: "puis ton poil gris et ton visage blesme / teust faict juger issu de Nicodesme / ou de Ioseph ou de ces peres sainctz / que on voyt grissars en nos eglizes painctz"; 176: "Maran trompeur masquant ung fainct courage / de beausemblant et de farde langaige / qui plain de ruse as seullement changé / de tes parans le bonnet orrangé." See also JeanJoël Bregeon and Yves de La Villetanet, "Le judaïsme à Nantes du XVI e siècle à la fin du XVII ${ }^{\mathrm{e}}$ siècle," Master's thesis, Université de Nantes, 1970, 133-35.

25 Pierre de Lancre, L'incredulité et mescreance du sortilege plainement convaincue (Paris: Nicolas Buon, 1622), 445-501. 
of Brittany justified its inquiry into the religious persuasion of candidates for naturalization with the need "to prevent people without faith and religion [...] from corrupting and infecting the integrity of good Christians with a false doctrine and bad example." ${ }^{26}$ Hostility erupted in the form of several local expulsions, two cases of popular riots, which occurred in St-Jean-de-Luz in 1619 and in Nantes in 1636,27 and repeated attempts at collective accusation, undertaken by the Parliament of Rouen in $1633^{28}$ and by the royal attorney in Toulouse in $1685 \cdot{ }^{29}$

However repulsive religious insincerity was for pious Catholics and rabbis, it was nothing short of a precondition for the general line of absolutist politics, which on the one hand imposed outward obedience to the ruler's religion, but on the other hand denied churches and tribunals the power to sanction private acts and beliefs. The political thereby created for a dissident minority has been described as a legal oxymoron ("une équivoque juridique"): ${ }^{30}$ on the one hand, professing Jews were officially banned from French soil since 1394 (with the exceptions of Metz and Avignon); on the other hand, "New Christians" had been welcomed and given economic privileges by the charter of Henry II since 1550 and, since 1574, were explicitly protected against inquiries regarding their religious life. ${ }^{31}$ These lettres patentes meant a privilege that should not be underestimated. By inviting explicitly and exclusively "les marchans et autres portugaiz appelez nouveaulx-chrétiens,"32 they granted a fiscal priority to Portuguese immigrants of Jewish ancestry over those who had none. At the same time, the otherwise comfortable situation of these New Christians in France during the seventeenth century was basically characterized by the illegality of any public manifestation of Jewish practice.

26 Guy Saupin, "Un mouvement de xénophobie anti-portugaise à Nantes dans les années 1630," in Monarchies, noblesses et diplomaties européennes: Mélanges en l'honneur de JeanFrançois Labourdette, ed. Jean-Pierre Poussou et al. (Paris: PUPS 2005), 49-6o, esp. 50: "pour empescher que gens sans foy et religion [...] ne viennent par faulce doctrine ou mauvais exemple à corrompre et infermer l'intégrité des vrays Chrestiens et gens de bien."

27 Jules Mathorez, "Notes sur l'histoire de la colonie portugaise à Nantes," Bulletin Hispanique 15 (1913): 316-39; esp. 332-34.

28 Cecil Roth, "Les marranes à Rouen: Un chapitre ignoré de l'histoire des Juifs de France, Revue des études juives 68 (1929): 113-55; Révah, “Autobiographie," 58-85.

29 Blamont, Le lion et le moucheron, 340-52.

$30 \quad$ Brigitte Bedos-Rezak, "Tolérance et Raison d'Etat: le problème juif," in L'État baroque 1610-1652: Regards sur la pensée politique de la France du premier XVII e siècle, ed. Henry Méchoulan (Paris: Vrin 1985), 243-87, esp. 248.

31 See the texts in Gérard Nahon, Les "Nations" juives portugaises du Sud-Ouest de la France (1684-1791) (Paris: Fundação Calouste Gulbenkian, 1981), 21-31.

Ibid., 22. 
This legal status corresponded to a restricted type of religious pluralism that European states practiced widely in the wake of the Reformation wars. In this model, authorities of the ruling faith offered to certain dissident groups a modus vivendi based on the legal protection of private religion (devotio domestica) or simply on tacit toleration. Willem Frijhoff has called attention to the fact that liberty of conscience was everywhere seen as a necessity rather than an ideal principle of state law (which it would only become at the turn of the eighteenth century). In the famous Dutch polemics between Justus Lipsius and Dirck Coornhert in the 1590s, the former had demanded that "the state should impose religious unity for the benefit of public order," while the latter, as Protestant politics in general, was wary to force minority members to either emigrate or perform sacred acts against their conscience. ${ }^{33}$ In Hamburg especially, a restricted interpretation of toleration prevailed among the Lutheran clergy and municipal authorities until 1785 , which accorded non-Lutherans the devotio domestica, but not more than this. ${ }^{34}$ This model was applied to the Sephardim, from the first contract the municipal powers made with them in $1612,{ }^{35}$ and it was again applied in Oliver Cromwell's famous letter to the Portuguese Jews of London in 1656. In France, however, where marriages and other personal status matters were handled by the two recognized churches, tacit toleration meant participation in the Catholic worship at least for life cycle events and periodical confession. The meaning of devotio domestica is thus fundamentally different in the Protestant and in the Catholic environment. In the Protestant countries, New Christian immigrants formed communities of a second-zone status, while Catholic monarchies de facto institutionalized a model of double religious practice, which allowed (or imposed) a cleavage of religious norms between the public and the domestic sphere.

This minority status could mean very different realities according to the time period and the city that we are talking about. Concerning the chronological cycles of greater or lesser liberty in France, it is well known that the reign of Henry IV, especially during the years $1603-1607$, as well as the subsequent regency of Marie de Medici between 1610-1617, tolerated Jewish deviance, even its public expressions, to a large extent. On the basis of a papal letter, the

33 Willem Frijhoff, "Religious Toleration in the United Provinces," in Calvinism and Religious Toleration in the Dutch Golden Age, ed. Ronnie Po-Chia Hsia and Henk Van Nierop (Cambridge: Cambridge University Press, 2002), 27-52, see 46.

34 Joachim Whaley, Religious Toleration and Social Change in Hamburg, 1529-1819 [1985] (Cambridge: Cambridge University Press, 2002); 35 .

35 Hiltrud Wallenborn, Bekehrungseifer, Judenangst und Handelsinteresse: Amsterdam, Hamburg und London als Ziele sefardischer Migration im 17. Jahrhundert (Hildesheim: Olms, 2003). 
queen's physician Elijah Montalto obtained his demand of public Jewish practice in Paris; "il n'entendoit se desguiser et contrefaire en sa profession, ains exercer librement sa religion judaïque." ${ }^{36}$ At the same time, but on the opposite corner of the kingdom, the big community of Saint-Jean-de Luz practiced the Jewish laws in a quite visible manner until the expulsion of $1619 .{ }^{37}$

The regency was followed by a restoration of strict religious control under Richelieu, who offered, at the same time, his protection to foreign merchants. The years of the Fronde after 1648 inaugurated a new period of relative religious openness, which allowed the regularization of Jewish life in the major Portuguese colony of the time, Saint-Esprit-lès-Bayonne. The pendulum swung back around the war year 1672, when the Catholic party of the "Dévots" came to power. From this moment, the church-oriented politics of Louis XIV also included harsh anti-Jewish measures against the Portuguese merchants in Marseille, Toulouse, and the Caribbean colonies. Double religious practice remained inevitable for the Jews of Bordeaux, who abandoned Christian life cycle rites for births only in the 1690 and for weddings in 1711; a distinctive Jewish cemetery was only acquired in $1724 .{ }^{38}$ As late as 1723 , the French kingdom, for the first time, officially recognized the presence of Portuguese Jews.

The important geographical differences between French regions in their Jewish policy should not be overlooked either. The Dukes of Gramont, who reigned over large territories in the southwestern border region and were, for a time, the royal governors of Bayonne, invited Jewish immigrants no less openly than Polish or Hungarian aristocrats did at the same time. Under the protection of the Duke, the big suburban community of Saint-Esprit-lès-Bayonne turned to a clearly confessionalized practice of Judaism in the middle of the century. ${ }^{39}$

36 Bedos-Rezak, "Tolérance et Raison d'Etat," 259. In 1614, the Parliament asks for a "recherche de toute nouvelles sectes et gens infâmes qui se sont coulez à Paris, es maisons des grands, pres de vostre cour, depuis peu d'annees, comme Anabaptistes, Juifs, magiciens et empoisonneurs." See ibid., 263.

37 Carsten L. Wilke, "Le rapport d'un espion du Saint-Office sur sa mission auprès des crypto-juifs de Saint-Jean-de-Luz (1611)," Sigila 16 (2006): 127-41.

38 Carsten L. Wilke, "Un moraliste rabbinique parmi les marranes de Bordeaux: Abraham de Oliveira et son Celo del temor de Dios (1661)," in L'Écriture de l'Histoire juive: Mélanges en l'honneur de Gérard Nahon, ed. Danièle Iancu-Agou and Carol Iancu (Paris and Louvain: Peeters, 2012), 355-72, esp. 356.

39 Wilke, "Un judaïsme clandestin en France au XVIIe siècle: Un rite au rythme de l'imprimerie," in Transmission et passages en monde juif, ed. Esther Benbassa (Paris: Publisud, 1997), 281-311, esp. 307-10. See also Gérard Nahon and Michèle Escamilla, "Matines juives à Bayonne au XVII e siècle au filtre du Saint Office," in Non solo verso oriente: Studi sull'ebraismo in onore di Pier Cesare Ioly Zorattini, ed. Magdalena Del Bianco Cotrozzi, Riccardo Di Segni and Marcello Massenzio (Florence: Casa Editrice Leo S. Olschki, 2014), 295-344. 
The Portuguese hired a rabbi and opened a synagogue in his house (1653), ${ }^{40}$ bought a cemetery (1654), obtained a new royal charter banning inquiries into their way of life $(1656),{ }^{41}$ and called a circumciser from Amsterdam, who circumcised hundreds of men and boys (1658). Hebrew first names appear henceforth on the tombstone inscriptions. The congregation itself used the name NefusotJeudah (Dispersed of Judah, from Is 11:12) in Hebrew correspondences, ${ }^{42}$ but refrained from mentioning it in public documents. The Jews of Saint-Esprit opened separate registers (now lost) for births, marriages, and deaths, which were started around the same time, the parish church being indemnified for the lost fees.

The arrival of the rabbi and circumciser in Saint-Esprit was reported in rabbinical sources as well as in inquisitorial informers' reports, of which I quote a portion:

What they name synagogue is the residence of the hakham [rabbi], who is the mentioned Isaac Israel de Avila. There was no particular place destined to the use as a synagogue, until the said Isaac Israel came to live in Bayonne; then they rented a big house for him to live in, which is the most remote of the village. Inside there is a big hall which they call the synagogue, it has the tabernacle, the Law, and many glass lamps around it. Here they all go to perform their prayers and other ceremonies. They call it explicitly the synagogue; in Spanish they say escuela [school] and in Hebrew medras. ${ }^{43}$

However, a witness attests that there was one significant restriction to religious freedom. "There is more freedom in Amsterdam than in Bayonne and Bordeaux, because in France, one has to baptise [the newborn children] for fear of the Catholic Frenchmen, even though they are circumcised afterwards, but in Amsterdam, Livorno, Pisa, and Florence one does not have to baptise

\footnotetext{
$40 \quad$ Kaplan, "Wayward New Christians," 31.

41 Nahon, Les "Nations" juives portugaises, 32-35.

42 Ibid., 261.

43 João Marques, 1672, in AHN, Inq., lib. 1145, fol. 31r-v: "Se a de aduertir q' la llamada sinagoga la casa en q' viue el jajan q' es el dho Isac Israel Dauila, porq avnq' de antes no auia lugar destinado $\mathrm{p}^{\mathrm{a}}$ la $\mathrm{d}^{\text {ha }}$ sinagoga, despues $\mathrm{q}^{\prime}$ fue a viuir a Bayona el $\mathrm{d}^{\text {ho }}$ Isac Israel se le alquilo vna casa grande en q' viuiese, q' es la vltima del lugar, y en ella ay vna sala grande, a q' llaman la sinagoga, donde estan el tavernaculo y la ley y muchas lamparas a alrededor de vidrio, y aqui acuden todos a hacer sus rezas y demas zeremonias y la llaman y apelidan la sinagoga, y en lenguaje española Escuela, y en el hebreo Megas."
} 
[them]." ${ }^{m 4}$ In practice, male children were handed from baptism by the priest immediately to circumcision by the rabbi.

Such a highly standardized degree of double life was impossible for the crypto-Jews of Bordeaux, Nantes, Paris, and Rouen, as there was no aristocratic lord to protect them in these places, and the ruling powers, that is, the regional parliament and the municipality, were lukewarm in their support (as in Bordeaux), or even hostile (as in Nantes). But even here, clerics sometimes agreed to free Portuguese persons from Catholic rituals as long as the corresponding fees were paid. Around 1638 in Bordeaux, the Franciscans became angry at the Jews who did not buy enough masses and requiems for their deceased. In protest, the monks started vandalizing tombstones in the part of their cemetery that was reserved for the Portuguese. This entire issue was resolved with the payment of two hundred silver ducats: the masses were paid without being held. ${ }^{45} \mathrm{~A}$ prisoner of the Spanish Inquisition who, in 1649, denounced the poet Antonio Enríquez Gómez, describes the conditions in Rouen with a characteristic anecdote: "The present witness stayed at his house whenever he visited Rouen, and there he remarked that they did all housework according to Hebrew ceremonies, or at least, this is what they affirmed. During one of these visits, the parish priest came in and asked the mentioned Antonio Enríquez Gómez why he did not come to confession, because not a single male member of his household had come for three years. Antonio Enríquez then went out with the priest, and when he returned, he said that he had dispatched the man with a doubloon." 46

44 Joseph Garcia de Leão, 1661, in AHN, Inq., lib. 1129, fols. 612v-613r: "en Bayona los judios, ni cumplen con la parrochia, ni confiesan, ni oyen misa, ni hacen offiçios a los difuntos ni los entierran en la Iglessia, y solo los acompaña los cuerpos sola la cruz y vn clerigo hasta el sitio donde los entierran en tierra virgen que tienen comprado para dicho efecto, y dejan alli los cuerpos, y los entierran los judios, y ha extrañado este tan gran maldad en los clerigos catholicos en acompañar la cruz los cuerpos de los Hebreos en semejantes entierros, ni tampoco se desposan ni velan con las çeremonias de la Iglesia, solo bautiçan los niños, para çircunçidarlos luego, por mano de vn Ministro, q tienen para eso"; 617v: "ay mas liuertad en Absterdam que en Bayona y Burdeos; porque en Françia se bautiçan por miedo de los Françeses catholicos, aunq' luego los çircunçidan, pero en Absterdam no los bautiçan, ni en Liorna, Pisa, ni Florençia."

45 Bartolomeu Vieira, 1642, in AHN, Inq., lib. 1103, fol. 122v, 142r; cf. Wilke, Jüdisch-christliches Doppelleben, 205.

46 Bartolomé López Coletero, 1649, in AHN, Inq., lib. 1111, fols. 2v-3r: "las diuersas vezes que estubo allí en Ruan este declarante, fue por posar sienpre en su cassa, y en ella les bio obrauan todo lo que azían con zeremonias ebreas, según ellos dezían; y vino vna bez $<3 r>$ en su presençia el cura de la peroquia; y dijo a dicho Antonio Enrríquez Gómez que cómo no se yva a confesar, pues auía tres años que no yva él ni ningún barón de su cassa; y el dicho Antonio Rodríguez [sic] fue con el dicho cura fuera de cassa; y quando boluió dijo que con vn doblón le auía despachado." See Wilke, Jüdisch-christliches Doppelleben, 314. 
João Pinto Delgado urges his coreligionists to move from France to Amsterdam in order to acquire salvation; but his poetic image of the Judaism practiced in France attests that the essential minimum of the Jewish festive calendar was practiced even there: the yearly fast on the Day of Atonement, the Passover ritual including the lamb's blood and the unleavened bread, and finally the observances connected to the Sabbath. ${ }^{47}$ This is confirmed by the Inquisition records, which remark the ubiquity of printed rituals and other Jewish books. In the Rouen bookstores, Amsterdam imprints by Rabbi Menasseh ben Israel were publicly on sale;48 and the commercial correspondents in the Sephardic community of Amsterdam sent prayer books on demand. ${ }^{49}$

There is no need, however, to suppose that Jewish customs only followed these texts, since visitors from Jewish communities in the Netherlands and Italy were quite frequent guests in the Franco-Portuguese communities. ${ }^{50}$ The sons of the above-mentioned doctor Montalto, who were living in Amsterdam, came for business visits. ${ }^{51}$ In 1631 , one of the sons celebrated Passover in Rouen with local Portuguese and with Estêvão Ares de Fonseca, another visitor from Amsterdam. As the latter would tell the Inquisition, the dinner was interrupted by the parish priest who had received a notice from an informer, and the foreign Jews had to leave the scene precipitously. ${ }^{52}$ The French travels of Dutch Jews became less risky since they collectively received a safe-conduct in March $1637 .^{53}$ Spinoza biographers even reflect a rumor that the philosopher was sent as a business agent to La Rochelle and Nantes at age eighteen. ${ }^{54}$

Révah, “Autobiographie," 106-7; Wilke, "Un judaïsme clandestin," 293.

48 Manuel Fernandes Vila Real, 1650, in Innocêncio da Silva, Dicionário bibliográfico português (Lisbon: Impr. Nacional, 1893), 16 (= vol. 9 of the supplement by Brito Aranha): 198: "em Ruão se vendiam dois dos seus livros publicamente, um de Resurreição dos mortos, e outro De Termino vitae."

49 Wilke, Jüdisch-christliches Doppelleben, 364 .

5o Natalia Muchnik, "Amsterdam et les groupements judéo-ibériques de France au XVII siècle," in Entre calvinistes et catholiques: Les relations religieuses entre la France et les PaysBas du Nord (XVI ${ }^{e}-X V I I I^{e}$ siècle), ed. Yves Krumenacker (Rennes: Presses Univ. de Rennes, 2010), 299-313.

51 Nicolás Broens, Monarquía y capital mercantil: Felipe IV y las redes comerciales portuguesas (1627-1635) (Madrid: Ediciones de la Universidad Autónoma de Madrid, 1989), 59.

52 Estêvão Ares de Fonseca, 1635, in AHn, Inq., lib. 1104, 79r-v; cf. Wilke, "Un judaïsme clandestin," 302.

53 Gérard Nahon, "Les rapports des communautés judéo-portugaises de la France avec celle d'Amsterdam au XVII e et au XVIII e siècles," Studia Rosenthaliana 10, no. 1 (1976): 37-78; 10, no. 2 (1976): 151-88, esp. 159 .

54 Jacques Dubarry, "Ephraïm Bueno, ami de Rembrandt, docteur en médecine de l'Université de Bordeaux," Revue d'histoire de la médecine hébräque 5 (1950): 17-23, esp. 23; reprinted in Mélanges d'histoire de la médecine hébraïque: Études choisies de la Revue 
In sum, the members of the Franco-Portuguese "Nation" self-consciously gave their religious life different degrees of "thickness" and publicity in accordance with the stable yet diverse local conditions that they encountered at the French destinations of converso immigration. Each one of those ten settlements followed its own rite and rhythm, Saint-Esprit living in the most Jewish and Nantes in the most Catholic way. But in all of them, crypto-Judaism was a semi-clandestine practice, which was publicly manifest in certain signs that attentive observers knew how to read. The Spanish agent Juan Bautista Villadiego could write that in France, a crypto-Jew was as recognizable as a black man among whites, "un negro entre los blancos." 55

How, then, must we imagine the public self-organization of this heterogeneous religious community? Its central framework was, of course, the "Nation portugaise," but we all know the multifaceted meanings this key term could have among early modern Sephardim. ${ }^{56}$ Simplifying things a bit one may detect a triple sense in the word: the "Nation" was the focus of an imaginary ethnic community (there is indeed a terminological coincidence with the "imagined communities" of modern nationalism, but this does not mean that there is an equivalence or even a continuity between the premodern and the modern meanings of the word); second, the "Nation" was a merchant corporation clearly defined in its rights and functions by the economic customs of the age; and thirdly, it took over various religious tasks and thus became in many cases the nucleus of a Jewish community.

In seventeenth-century trade cities, the different merchant nations were autonomous organizations that had regular assemblies and elected judges, arbiters, and syndics who negotiated with the authorities. In Antwerp, as this is well known through the studies by Jean-Albert Goris and Hans Pohl, the Portuguese "Nation" possessed a building and regular officials, called consuls. ${ }^{57}$

d'histoire de la médecine hébrä̈que (1948-1985), ed. Gad Freudenthal and Samuel S. Kottek (Leiden: Brill, 2003), 217-22, esp. 222.

55 Juan Bautista Villadiego, 16 March 1633, in AHN, Inq., leg. 171, exp. 4, vol. I, fol. 8or: "de la manera y con la certeça que se distingue y pareçe vn negro, entre los blancos con la misma se saue y se conoçen en estas partes por los de su naçion los que son o no judios."

56 Miriam Bodian, Hebrews of the Portuguese Nation: Conversos and Community in Early Modern Amsterdam (Bloomington: University of Indiana Press, 1999), 6; Federica Ruspio, La nazione portoghese: Ebrei ponentini e nuovi cristiani a Venezia (Turin: Silvio Zamorani editore, 2007), 15; Daviken Studnicki-Gizbert, A Nation upon the Ocean Sea: Portugal's Atlantic Diaspora and the Crisis of the Spanish Empire, 1492-1640 (Oxford: Oxford University Press, 2007), 9-11.

57 Jan Albert Goris, Étude sur les colonies marchandes méridionales (Portugais, Espagnols, Italiens) à Anvers de 1488 à 1567: Contribution à l'histoire des débuts du capitalisme moderne (Louvain: Librairie Universitaire, 1925); Hans Pohl, Die Portugiesen in Antwerpen, 15671648: zur Geschichte einer Minderheit (Wiesbaden: Steiner, 1978). 
As notarial records show, the Portuguese merchants in France also elected local representatives for certain tasks, but the (still unresearched) internal organization of their "Nation" seems to have been of a much more informal kind. The most ancient conserved register of deliberations of the Jewish "Nation" of Bordeaux, edited by Simon Schwarzfuchs, starts only in 1711 and mentions a community leadership composed of one president (sindic or gabbay) and two deputies (adjoints or parnassim). ${ }^{58}$ Certain patterns of this organization may go back to the time when the "Nation" had merely economic tasks. For example, in Bordeaux, on 22 July 1641, the Portuguese merchants gathered and elected a syndic who would negotiate the naturalization tax at the royal court of Paris, a board of eight men who had to decide on the share of every member in the tax rolls, one receptor who was entitled to collect the money, plus various members who would send the sum in bills of exchange to António Pereira da Silva, court banker in Paris. ${ }^{59}$

More than formal self-organization, rituals related to time and space shaped the Franco-Portuguese "Nation" in the seventeenth century. We must first take into account that in the urban space Portuguese merchants observed a degree of clustering that is atypical for merchants of the time. The joint settlement of Portuguese traders near the bridge and square of Saint-Esprit-lès-Bayonne shows this clustering most perfectly. The Portuguese of Bordeaux mostly lived in two parishes slightly outside the city center. ${ }^{60}$ Preferred neighborhoods in Rouen were the streets near the port and in Nantes, the western faubourg of La Fosse. In Paris, most of the Portuguese merchants lived in the parish of SaintEustache near the Halles, which formed a kind of financial district.

In Nantes, the members of the Spanish merchant corporation, the Contratación, congregated for deliberations in the chapel "Nostre Dame des Espaignols" in the Franciscan church of the rue St Jean. ${ }^{61}$ In Bordeaux, the Franciscans offered a similar facility for the Iberian merchants; Cecil Roth's

$5^{8}$ Simon Schwarzfuchs, Le registre des délibérations de la Nation Juive Portugaise de Bordeaux (1711-1787) (Paris: Fundação Calouste Gulbenkian, 1981), 11-12.

59 Bordeaux, Archives départementales de la Gironde, $3 \mathrm{E}-15241,22$ July 1641: "Ilz ont esté choisis \& nommes par la Nation portugoise residante aud bourd $^{\mathrm{x}}$ pour faire la taxe sur jcelle nation pour la naturalisation [...] lade nation ont esleu et nommé, eslisent et nomment le sieur Jean da Costa Fortade lui donnant pouuoir de recepuoir desds portugois les sommes a quoy ilz ont esté par lade taxe et en bailler quittance a chascun deux."

6o Bertrand Gautier and Peter Voss, "Les communautés marchandes étrangères dans l'espace urbain bordelais (1620-1715)," in Les étrangers dans la ville, ed. Bottin et Calabi, 329-46, esp. 334 .

61 Paul Jeulin, "Une page de l'histoire du commerce nantais du XVI ${ }^{\mathrm{e}}$ siècle au début du XVIII ${ }^{\mathrm{e}}$ siècle: Aperçus sur la Contractation de Nantes (1530 environ-1733)," Annales de Bretagne 40 (1932): 284-331, esp. 289-9o. 
suspicion of crypto-Jewish gatherings here seems to be far-fetched. ${ }^{62}$ Indeed our sources from French cities attest unanimously that the Portuguese merchants used to gather outdoors. In Bordeaux, they met around the "Medusa Fountain" on the Place du Mirail, a small triangular place in the middle of their neighborhood, which they seem to have turned into an Iberian exclave. ${ }^{63}$ The Portuguese of Rouen met at the merchants' exchange, a place lined with trees that stretched between the riverside and the city walls outside of the Porte de l'Estrade. ${ }^{64}$ In the eyes of a local poet, the mustached Iberians, nick-named bourgais de Ierusalem, "burgers of Jerusalem," strutted across their section on the quay as gallantly as if each of them were "a cock among his hen."65

Distinctive leisure venues seem to have played a role for the social and even religious life of the communities. Some of the Portuguese at Saint-Esprit ran private gambling-houses where their coreligionists used to meet in clandestine prayer-rooms on the upper floor. ${ }^{66}$ One witness declared that the crypto-Jews of Saint-Esprit congregated around 1642 in "the house next to the poplar."67 A poem enumerating the beer-houses of Rouen and their clients evokes a similar picture, reporting that "the salt traders and the Portuguese" had their special taverns near the Old Arsenal (Clos des Gallées) on the southern side of the river. ${ }^{68}$ Further afield in that suburban neighborhood, Manuel Rodrigues Nunes rented a country house (vna huerta) where larger groups could spend the Jewish holidays. ${ }^{69}$ Correligionists in Bordeaux customarily celebrated the

62 Cecil Roth, History of the Marranos (New York: Schocken, 1974), 224.

63 Wilke, "Un judaïsme clandestin," 300.

64 On the history of the square, see [François Farin,] Histoire de la ville de Rouen (Rouen: Louis du Souillet, 1731), 2: 147 .

65 David Ferrand, La Muse Normande, publiée d'après les livrets originaux, 1625-1653, avec introduction, notes et glossaire par A. Héron (Rouen: Imprimerie Espérance Cagniard, 1891), 2: 191: "Ces circoncis qui ont le dequay / de faire ichite les brauaches, / Qui se pourgaudent su su quay / Leuant les croqs de leu moustaches" [Those circumcized ones who have the wealth to play the brave guys here, strutting on their quay with the ends of their moustaches turned upwards]. See also 2: 91: "Se brauant comme vn cocq sieuuy de ses gueline / O comme vn Portugais dans la bourse o marchands."

66 Wilke, "Un judaïsme clandestin," 306.

67 Francisco López Villanueva, 1667, in AHN, Inq., leg. 162, exp. 1, fol. 116r: "se juntaban en la casa que està junta al alamo en el varrio de santispiritus y que se tratauan publicam ${ }^{\text {te }}$ como judios."

68 Jules Mathorez, "Notes sur les Espagnols en France depuis le XVIe siècle jusqu'au règne de Louis XIII," Bulletin Hispanique 16 (1914): 337-71, esp. 361, quotes the popular verses: "Les tavernes de Saint-Gervais / Sont pour les Cauchois [coachmen] et Bouveetz [oxmen]. I Hors le Pont, au clos des Gallez, / Pour Sannietz [salt traders] et Portugallais."

69 Wilke, Jüdisch-christliches Doppelleben, 325 . 
Sabbath "going for a walk in the countryside during the afternoon."70 Sabbath gatherings in Saint-Esprit needed less discretion, yet the rabbi's house that served as synagogue was on the outskirts of the suburb, and circumcisions were hosted by a Portuguese in the country town of Peyrehorade "para mayor secreto."71 Crypto-Jewish sociability and religious practice thus relied not only on private homes as in the Iberian countries, but on a complicated imbrication of spaces. The Portuguese appropriated and, in a way, Judaized their preferred trading sites near the port, their meeting places in residential areas, certain semi-public houses of entertainment, and protected areas of evasion out of town.

It is difficult to reconstruct how in the southern French cities the "Nation" evolved from a Christian merchant corporation into a local Jewish community. The care for the ethnic cemeteries was always a task of the "Nation," but there was not, as far as I know, any communal organization of prayer during the first half of the century. Private schools for children, with a more or less pronounced Jewish content, were offered by various individuals, but all documents about them come from Bordeaux. ${ }^{72}$ Around 1648 , the white-bearded Simão Rodrigues Bueno is mentioned there as the schoolmaster of the Portuguese. ${ }^{73}$

It would be, in sum, a mistake to separate too clearly between the economic and the religious life of the "Nation." Its flexible religious identity responded to the specific political situation of the French localities as well as to the commercial broker function within the Catholic world. However, the "Nation's" adjustment to the circumstances was not a zero-sum balance between pious fervor and adverse conditions, as the surprising development in the 1650 s shows. At the time, most of the men of Saint-Esprit worked over long stretches of the year in Spain as merchants and tax-collectors, and they obviously led a life in conformity with Catholic public ritual. This regular wandering in a land which outlawed Judaism might be expected to relax Jewish religious discipline at home. But the exact opposite is true. During the years around 1660 in which the phenomenon of "return to Spain" was strongest, when the entire economy of the community in Saint-Esprit was shaped by systematic border-crossing, risk-taking, and religious duplicity, precisely at that point, as we have already seen, a halakhic framework of religious identity emerges. It was for traders that came back from Spain only around the High Holidays and Passover that the synagogue service was given a more normative shape. It was for families that

70 Afonso Lopes, 1662, in AHN, Inq., lib. 1131, fol. 197r.

71 Simão Nunes Neto, 1665, in AHN, Inq., lib. 1139, fol. 275v.

72 Wilke, “Un judaïsme clandestin," 301-2.

73 António Martins, 1661, in AHN, Inq., lib. 1129, fol. 344v-346v, 356v-357r. 
were separated most of the year, the men working in Spain and the women staying on the French side, that rabbinic marriage was seen as important.

An interesting case in point is the adoption of the normative circumcision rite. Among the French Portuguese, circumcision was practiced in an incomplete way, or by mere puncturing of the foreskin. ${ }^{74}$ One witness, who had been in Rouen, declared in 1635 that business travelers had a small piece of flesh cut from the left side of the foreskin, in the form of a letter C, so that if these men were arrested in Spain, the inquisitors could not use this lesion as formal evidence of apostasy. ${ }^{75}$ However, around the year 1658 , precisely when most young men went to work in Spain, the halakhic practice of full circumcision was generalized. In some cases, a young man would be asked to submit to circumcision and a Jewish marriage before being allowed to travel to Spain. ${ }^{76}$ Circumcision was not the rite of passage symbolizing the final adoption of a Jewish way of life, but inversely an insurance policy that should prevent a traveler from staying too long in Spain and from becoming too intimate with its inhabitants.

It becomes clear at this point that there was a complementary relationship between the more developed Jewish religious ritual in France and the dissimulation practiced in Spain. To put it in the terminology of Gérard Nahon, the more bipolar the biographies of the Pyrenean traders became, the more their community leaders tended to strengthen the Jewish pole. And the more French Jewish practice became regularized, the more Spanish crypto-Judaism could be reduced to secret "declarations" between its adherents, that is, to a meta-ritual practice of talking about Judaism instead of actually practicing it.

This compensation strategy may also account for the rich literary creativity that developed among the French crypto-Jews. The printed and the clandestine

74 Yosef Kaplan, "This Thing Alone Will Preserve Their Nation. Forever': Circumcision and Conversion in the Early Modern Western Sephardic Communities," in The Conversos and Moriscos in Late Medieval Spain and Beyond, vol. 3, Displaced Persons, ed. Kevin Ingram (Leiden: Brill, 2015), 218-43, esp. 228.

75 Estêvão Arês da Fonseca, 1635, in AHN, Inq., lib. 1107, fol. 41r: "y el segundo modo de circuncision, que se executa en los que an de ir y venir por aca para que no sean conoçidos por circuncidados, y que sean conoçidos de los judios, es cortarles de la parte izquierda del prepuçio vna pequeña parte a modo de media luna, $\mathrm{v}$ de una $\mathrm{C}$, y que aduirtiendo en ello los inspectores es facil de conoçer, excluyendo la excusa ordinaria que suelen dar de que aquella scissura se les a causado de alguna enfermedad o achaque del miembro."

76 Wilke, "Un judaïsme clandestin," 309; Nahon, Juifs et judaïsme, 53; Wilke "Contraband for the Catholic King," 68. See also, unaware of these publications, Aliza MorenoGoldschmidt, "Integración religiosa y social de los conversos en las comunidades de la diáspora sefardí occidental a la luz de fuentes inquisitoriales," Sefarad 76, no. 1 (2016): 159-96, esp. $166-71$. 
works include the published poetry by João Pinto Delgado, Antonio Enríquez Gómez, and his son Diego Enríquez Basurto, where the reader often finds biblical references and reflections on religion in such a cryptic and ambiguous style that readers of both religions can accommodate them. The extant literary production also includes some clandestine polemical writings against the Inquisition, the Catholic Church, or the Christian religion at large. Intense theological controversies flared up periodically during the quarter century that elapsed between Rabbi Mortera's correspondence in 1631 and the missionary intervention of Jérôme Lopes, a Bordeaux churchman stemming from one of the major families of the "Nation." The latter's missionary campaign was assisted by the more protracted efforts of the Rouen merchant António da Cunha, author in 1656 of a printed pamphlet defending the Christian interpretation of Isaiah $53 .{ }^{77} \mathrm{~A}$ few years later, a literary circle among the Jews of Bordeaux left two manuscript works with meditations on religious morals. ${ }^{78}$

Two of the writers belonging to the "Nation," Manuel Fernandes Vila Real and Antonio Enríquez Gómez, were also authors of political treatises. In them, they express creative cultural compromises typical of the age of confessionalization. In particular, they defend the absolutist doctrine that imposed a unique religion on public life, but demanded liberty of conscience for the private sphere, endorsing exactly the policy adopted by France toward its semi-clandestine Jews. Successful cross-confessional options of early modern thought, such as introverted piety, esotericism, and skepticism, are also manifest in these authors' symbolic self-image. ${ }^{79}$ Enríquez Gómez's cousin finds warm words for the situation in France even when he reports it to the Inquisition: "Having communicated with the mentioned practicing Jews, he has noticed that all of those whom the Inquisition has [imprisoned and] released return to Judaism when they arrive in a free country such as France. Many of them justify this because they had been mistreated and despised by the Old Christians, and they see that the Jews give them hospitable reception and honor, particularly in France, where even the Christians give them help and a warm welcome."80

77 Carsten L. Wilke, "Midrashim from Bordeaux: A Theological Controversy inside the Portuguese Jewish Diaspora at the Time of Spinoza's Excommunication," European Journal of Jewish Studies 6, no. 2 (2012): 207-47.

78 Wilke, "Un moraliste rabbinique," 360.

79 Carsten L. Wilke, "Políticos franceses, criptojudíos portugueses y un poeta español desterrado," in Antonio Enríquez Gómez, un poeta entre santos y judaizantes, ed. J. Ignacio Díez and Carsten L. Wilke (Kassel: Reichenberger, 2015), 204-27.

80 Francisco Luis Enríquez de Mora, 1663, in AHN, Inq., lib. 1139, fol. 320v: "Y como quien a comunicado con los dichos obserbantes, a reconoçido que todos se buelben en saliendo 
There is no doubt that many of the clandestine Jews were fully content with staying in France and did so of their own will. For moralists such as Mortera, it was important to present this outcome as the result of a misguided religious choice. Out of greed, he claimed, some compatriots had picked the wrong attitude from a wide range of Judaisms, the complete one of Amsterdam, the almost complete one of Saint-Esprit, the rather incomplete one of Bordeaux and Rouen, and the almost inexistent practice in Spain. When migratory facts had to be translated into the mindset of rabbis or inquisitors, the trips across the Franco-Spanish border were inevitably interpreted as expressions of religious doubt, just as in the retrospective perception of Pinto Delgado, the move to Amsterdam was seen as the outcome of a sincere religious quest. The historian, however, should complicate such moralistic interpretations with the help of a life-worldly approach, which would allow to understand the "French model" as a religious attitude in its own right and as an important node in the dynamic network of the Western Sephardic diaspora. We should take note of the fact that migrants generally adapted their religious ideas and feelings to a complex framework of French religious policy, local conditions, the family enterprise strategy, the evolution of global commerce, and the group dynamics of their ethnic trade network. This does not mean that their approach to religion was merely opportunistic. Such an interpretation is contradicted by the important and intense religious debates that shook the clandestine Jews of France. Passionate dogmatic controversies and a marked curiosity for things Jewish prove the undiminished relevance of matters of creed inside this social world of manifold compromises.

\section{Bibliography}

Amsterdam, Ets Haim, cod. 48 A 21.

Anonym. "Satyre contre un Juif, 1568." Bulletin du bibliophile et du bibliothécaire 33 (1867): 175-80.

Bedos-Rezak, Brigitte. “Tolérance et Raison d'Etat: le problème juif." In L'État baroque 1610-1652: Regards sur la pensée politique de la France du premier XVII ${ }^{e}$ siècle. Edited by Henry Méchoulan, 243-87. Paris: Vrin 1985.

de las Inquisiciones al judaísmo, si se hallan en parte libre como lo es Françia. Y muchos dellos se fundan en que se ben avatidos y menospreçiados de los cristianos biejos, y ben que los judios los haçen buena acojida y los honran, y en Françia en particular, donde avn los cristianos les dan lado y buen lugar." 
Blamont, Jacques. Le lion et le moucheron: Histoire des marranes de Toulouse. Paris: Odile Jacob, 2000.

Bodian, Miriam. Hebrews of the Portuguese Nation: Conversos and Community in Early Modern Amsterdam. Bloomington: University of Indiana Press, 1999.

Bordeaux, Archives départementales de la Gironde, ${ }_{3} \mathrm{E}-15241$.

Bottin, Jacques. "La redistribution des produits américains par les réseaux marchands rouennais (1550-1620)." In Dans le sillage de Colomb: L'Europe du Ponant et la découverte du Nouveau Monde (1450-1650). Edited by Jean-Pierre Sanchez, 27-39. Rennes: Presses universitaires de Rennes, 1995.

Bregeon, Jean-Joël, and Yves de La Villetanet. "Le judaïsme à Nantes du XVI e siècle à la fin du XVIIe siècle." Master's thesis, Université de Nantes, 1970.

Broens, Nicolás. Monarquía y capital mercantil: Felipe IV y las redes comerciales portuguesas (1627-1635). Madrid: Ediciones de la Universidad Autónoma de Madrid, 1989.

Brunelle, Gayle. "Jewish Jews and Catholic Jews: Confessionalization and Portuguese New Christians in Early Modern Rouen." In Trouver sa place: Individus et communautés dans l'Europe modern. Edited by Antoine Roullet, Olivier Spina and Nathalie Szczech, 101-16. Madrid: Casa de Velázquez, 2011.

Brunelle, Gayle. "Migration and Religious Identity: The Portuguese of SeventeenthCentury Rouen." The Journal of Early Modern History 7, nos. 3-4 (November, 2003): 283-311.

Brunelle, Gayle. The New World Merchants of Rouen, 1559-1630. Kirksville, MO: Sixteenth Century Journal Publishers, 1991.

Dubarry, Jacques. "Ephraïm Bueno, ami de Rembrandt, docteur en médecine de l'Université de Bordeaux." Revue d'histoire de la médecine hébraïque 5 (1950): 17-23. Reprinted in Mélanges d'histoire de la médecine hébraïque: Études choisies de la Revue d'histoire de la médecine hébraïque (1948-1985). Edited by Gad Freudenthal and Samuel S. Kottek, 217-22. Leiden: Brill, 2003.

Escamilla-Colin, Michèle. "Rouen et la diaspora ibérique." Cahiers du C.R.I.A.R. 15 (1995): 27-48.

Farin, François. Histoire de la ville de Rouen. 2 vols. Rouen: Louis du Souillet, 1731.

Ferrand, David. La Muse Normande. Publiée d'après les livrets originaux, 1625-1653, avec introduction, notes et glossaire par A. Héron. 5 vols. Rouen: Imprimerie Espérance Cagniard, 1891-1894.

Frijhoff, Willem. "Religious Toleration in the United Provinces." In Calvinism and Religious Toleration in the Dutch Golden Age. Edited by Ronnie Po-Chia Hsia and Henk Van Nierop, 27-52. Cambridge: Cambridge University Press, 2002.

Gautier, Bertrand, and Peter Voss. "Les communautés marchandes étrangères dans l'espace urbain bordelais (1620-1715)." In Les Étrangers dans la ville: Minorités et espace urbain du bas Moyen Age à l'époque moderne. Edited by Jacques Bottin and Donatella Calabi, 329-46. Paris: Éditions de la Maison des Sciences de l'Homme, 1999. 
Goris, Jan Albert. Étude sur les colonies marchandes méridionales (Portugais, Espagnols, Italiens) à Anvers de 1488 à 1567: contribution à l'histoire des débuts du capitalisme moderne. Louvain: Librairie Universitaire, 1925.

Graizbord, David L. Souls in Dispute: Converso Identities in Iberia and the Jewish Diaspora, 1580-1700. Philadelphia: University of Pennsylvania Press, 2004.

Israel, Jonathan I. "El comercio de los judíos sefardíes de Amsterdam con los conversos de Madrid a través del suroeste francés." In Familia, religión y negocio: El sefardismo en las relaciones entre el mundo hispánico y los Países Bajos en la Edad Moderna. Edited by Jaime Contreras et al., 373-90. Alcalá: Centro de Estudios Carlos de Amberes y el Instituto Internacional de Estudios Sefardíes y Andalusíes, Universidad de Alcalá, 2003.

Jeulin, Paul. "Une page de l'histoire du commerce nantais du XVI ${ }^{\mathrm{e}}$ siècle au début du XVIII ${ }^{\mathrm{e}}$ siècle: Aperçus sur la Contractation de Nantes (1530 environ-1733)." Annales de Bretagne 40 (1932): 284-331.

Kaplan, Yosef. "Between Christianity and Judaism in Early Modern Europe: The Confessionalization Process of the Western Sephardi Diaspora." InJudaism, Christianity, and Islam in the Course of History: Exchange and Conflicts. Edited by Lothar Gall and Dietmar Willoweit, 307-41. Munich: Oldenbourg, 2011.

Kaplan, Yosef. From Christianity to Judaism: The Story of Isaac Orobio de Castro. Trans. Raphael Loewe. Oxford: The Littman Library of Jewish Civilization, 1989.

Kaplan, Yosef. “This Thing Alone Will Preserve Their Nation. Forever:' Circumcision and Conversion in the Early. Modern Western Sephardic Communities." In The Conversos and Moriscos in Late Medieval Spain and Beyond. Vol. 3. Displaced Persons. Edited by Kevin Ingram, 218-43. Leiden: Brill, 2015.

Kaplan, Yosef. "Wayward New Christians and Stubborn New Jews: The Shaping of a Jewish Identity." Jewish History 8, nos. 1-2 (1994): 27-41.

Lancre, Pierre de. L'incredulité et mescreance du sortilege plainement convaincue. Paris: Nicolas Buon, 1622.

Madrid, Archivo Histórico Nacional [AHN], Inq., leg. 162, exp. 1.

Madrid, AH N, Inq., leg. 171, exp. 4.

Madrid, AHN, Inq., lib. 1103 .

Madrid, AH N, Inq., lib. 1104.

Madrid, AHN, Inq., lib. 1107.

Madrid, AH N, Inq., lib. 1111.

Madrid, AH N, Inq., lib. 1129.

Madrid, AHN, Inq., lib. 1131.

Madrid, AH N, Inq., lib. 1139.

Madrid, AH N, Inq., lib. 1145 .

Mathorez, Jules. "Notes sur l'histoire de la colonie portugaise à Nantes." Bulletin Hispanique 15 (1913): 316-39. 
Mathorez, Jules. "Notes sur les Espagnols en France depuis le XVI ${ }^{\mathrm{e}}$ siècle jusqu'au règne de Louis XIII." Bulletin Hispanique 16 (1914): 337-71.

Melammed, Renée Levine. A Question of Identity: Iberian Conversos in Historical Perspective. New York: Oxford University Press, 2004.

Moreno-Goldschmidt, Aliza. "Integración religiosa y social de los conversos en las comunidades de la diáspora sefardí occidental a la luz de fuentes inquisitoriales." Sefarad 76, no. 1 (2016): 159-96.

Muchnik, Natalia. "Amsterdam et les groupements judéo-ibériques de France au XVII ${ }^{\mathrm{e}}$ siècle." In Entre calvinistes et catholiques: Les relations religieuses entre la France et les Pays-Bas du Nord (XVI ${ }^{e}-X V I I I^{e}$ siècle). Edited by Yves Krumenacker, 299-313. Rennes: Presses Univ. de Rennes, 2010.

Muchnik, Natalia. "De la défense des 'impurs' à la critique du Saint-Office: Le plaidoyer de Juan Bautista de Villadiego (1636)." Revue d'histoire ecclésiastique 101 (2006):1014-38.

Muchnik, Natalia. De paroles et de gestes. Constructions marranes en terre d'Inquisition. Paris: Éditions de l'EHESS, 2014.

Nahon, Gérard. Juifs et judaïsme à Bordeaux. Bordeaux: Mollat, 2003.

Nahon, Gérard. "La 'Nation portugaise' de Saint-Esprit-lès-Bayonne du XVI e au XVIII ${ }^{\mathrm{e}}$ siècle: Escale ou havre de grâce?" In 1492/1992: L'Exode des juifs d'Espagne vers Bayonne. Edited by Maïté Lafourcade, 1-30. Bayonne: Université de Pau, 1993.

Nahon, Gérard. "Le modèle français du marranisme: Perspectives nouvelles." In Inquisição: Ensaios sobre mentalidade, heresias, e arte. Edited by Anita Novinsky and Maria Luiza Tucci Carneiro, 227-65. Rio de Janeiro: Edusp, 1992.

Nahon, Gérard. "Le modèle français du marranisme (XVI ${ }^{\mathrm{e}}-\mathrm{XVIII}{ }^{\mathrm{e}}$ siècles)." Annuaire de l'École Pratique des Hautes Études, Cinquième section: Sciences religieuses 90 (1982): 264 .

Nahon, Gérard. Les “Nations” juives portugaises du Sud-Ouest de la France (1684-1791). Paris: Fundação Calouste Gulbenkian, 1981.

Nahon, Gérard. "Les rapports des communautés judéo-portugaises de la France avec celle d'Amsterdam au XVII ${ }^{\text {e }}$ et au XVIII ${ }^{\text {e }}$ siècles." Studia Rosenthaliana 10, no. 1 (1976): 37-78; 10, no. 2 (1976): 151-88.

Nahon, Gérard. Métropoles et périphéries séfarades d'Occident: Kairouan, Amsterdam, Bayonne, Bordeaux, Jérusalem. Paris: Cerf, 1993.

Nahon, Gérard, and Michèle Escamilla. "Matines juives à Bayonne au XVII e siècle au filtre du Saint Office." In Non solo verso oriente: Studi sull'ebraismo in onore di Pier Cesare Ioly Zorattini. Edited by Magdalena Del Bianco Cotrozzi, Riccardo Di Segni and Marcello Massenzio, 295-344. Florence: Casa Editrice Leo S. Olschki, 2014.

Pohl, Hans. Die Portugiesen in Antwerpen, 1567-1648: zur Geschichte einer Minderheit. Wiesbaden: Steiner, 1978.

Révah, Israël Salvator. "Autobiographie d'un Marrane: Edition partielle d'un manuscrit de João (Moseh) Pinto Delgado." Revue des études juives 119 (1961): 41-130. 
Révah, Israël Salvator. "Les Marranes.," Revue des études juives 118 (1959-1960), 29-77.

Roth, Cecil. History of the Marranos. New York: Schocken, 1974.

Ruspio, Federica. La nazione portoghese: Ebrei ponentini e nuovi cristiani a Venezia. Turin: Silvio Zamorani editore, 2007.

Salomon, Herman P. "Haham Saul Levi Morteira en de Portugese Nieuw-Christenen." Studia Rosenthaliana 10 (1976): 127-41.

Saupin, Guy. "Un mouvement de xénophobie anti-portugaise à Nantes dans les années 1630." In Monarchies, noblesses et diplomaties européennes: Mélanges en l'honneur de Jean-François Labourdette. Edited by Jean-Pierre Poussou et al., 49-6o. Paris: PUPS 2005 .

Schwarzfuchs, Simon. Le registre des délibérations de la Nation Juive Portugaise de Bordeaux (1711-1787). Paris: Fundação Calouste Gulbenkian, 1981.

Silva, Innocêncio da. Dicionário bibliográfico portugués. Vol. 16 (= vol. 9 of the supplement by Brito Aranha). Lisbon: Impr. Nacional, 1893 .

Studnicki-Gizbert, Daviken. A Nation upon the Ocean Sea: Portugal's Atlantic Diaspora and the Crisis of the Spanish Empire, 1492-1640. Oxford: Oxford University Press, 2007.

Szajkowski, Zosa. "The Marranos and Sephardim of France," in The Abraham Weiss Jubilee Volume, ed. Samuel Belkin (New York: The Abraham Weiss Jubilee Committee, 1964), 107-127.

Szajkowski, Zosa. "Population Problems of Marranos and Sephardim of France." Proceedings of the American Academy for Jewish Research 27 (1958): 83-105.

Wallenborn, Hiltrud. Bekehrungseifer, Judenangst und Handelsinteresse: Amsterdam, Hamburg und London als Ziele sefardischer Migration im 17. Jahrhundert. Hildesheim: Olms, 2003.

Whaley, Joachim. Religious Toleration and Social Change in Hamburg, 1529-1819. Cambridge: Cambridge University Press, 2002 [1985].

Wilke, Carsten L. "Contraband for the Catholic King: Jews of the French Pyrenees in the Tobacco Trade and Spanish State Finance." In Purchasing Power: The Economics of Modern Jewish History. Edited by Rebecca Kobrin and Adam Teller, 46-70. Philadelphia: University of Pennsylvania Press, 2015.

Wilke, Carsten L. Jüdisch-christliches Doppelleben im Barock: Zur Biographie des Kaufmanns und Dichters Antonio Enríquez Gómez. Frankfurt:, Peter Lang, 1994.

Wilke, Carsten L. "Le rapport d'un espion du Saint-Office sur sa mission auprès des crypto-juifs de Saint-Jean-de-Luz (1611)," Sigila 16 (2006): 127-41.

Wilke, Carsten L. "Midrashim from Bordeaux: A Theological Controversy inside the Portuguese Jewish Diaspora at the Time of Spinoza's Excommunicatio." European Journal of Jewish Studies 6, no. 2 (2012): 207-47.

Wilke, Carsten L. "Políticos franceses, criptojudíos portugueses y un poeta español desterrado." In Antonio Enríquez Gómez, un poeta entre santos y judaizantes. Edited by J. Ignacio Díez and Carsten L. Wilke, 204-27. Kassel: Reichenberger, 2015. 
Wilke, Carsten L. "Un judaïsme clandestin en France au XVII e siècle: Un rite au rythme de l'imprimerie." In Transmission et passages en monde juif. Edited by Esther Benbassa, 281-311. Paris: Publisud, 1997.

Wilke, Carsten L. "Un moraliste rabbinique parmi les marranes de Bordeaux: Abraham de Oliveira et son Celo del temor de Dios (1661)." In L'Écriture de l'Histoire juive: Mélanges en l'honneur de Gérard Nahon. Edited by Danièle Iancu-Agou and Carol Iancu, 355-72. Paris and Louvain, Peeters, 2012.

Zink, Anne. "Communautés et corps social: Les juifs à Saint-Esprit-lès-Bayonne du XVII ${ }^{\mathrm{e}}$ au début du XIX ${ }^{\mathrm{e}}$ siècle." In Les Étrangers dans la ville: Minorités et espace urbain du bas Moyen Age à l'époque moderne. Edited by Jacques Bottin and Donatella Calabi, 313-28. Paris: Éditions de la Maison des Sciences de l'Homme, 1999.

Zink, Anne. "Une niche juridique: L'installation des Juifs à Saint-Esprit-lès-Bayonne au

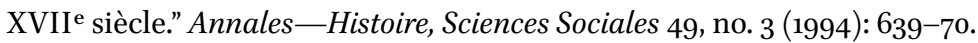

